\title{
Isolation and Structure Elucidation of Desferrioxamine B and the New Desferrioxamine B2 Antibiotics from a Brown Marine Macroalga Carpodesmia tamariscifolia Associated Streptomyces Isolate
}

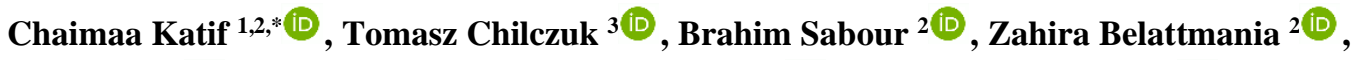 \\ Adil Hilmi ${ }^{1}\left(\mathbb{D}\right.$, Timo Horst Johannes Niedermeyer ${ }^{3(\mathbb{D})}$, Mustapha Barakate ${ }^{1,4}(\mathbb{D}$
}

1 Laboratory of Microbial Biotechnology, Agrosciences, and Environment, Faculty of Sciences Semlalia, Cadi Ayyad University, Marrakech, Morocco; chaimaa.katif@edu.uca.ac.ma, (C.K); nosocomios@gmail.com, (A.H); mbarakate@uca.ac.ma, (M.B);

2 Laboratory of Plant Biotechnology, Ecology and Ecosystem Valorization - R.U. Phycology, Blue Biodiversity \& Biotechnology, Faculty of Sciences, Chouaib Doukkali University, El Jadida, Morocco; sabour.b@ucd.ac.ma (B.S); belattmania.z@ucd.ac.ma_(Z.B);

3 Department of Pharmaceutical Biology/Pharmacognosy, Institute of Pharmacy, University of Halle-Wittenberg, Halle, Germany;tomasz.chilczuk@pharmazie.uni-halle.de, (T.C); timo.niedermeyer@pharmazie.uni-halle.de (T.N);

4 Mohammed IV Polytechnic University (UM6P), BioVal program, AgroBiosciences, 43150 Benguerir, Morocco

* Correspondence: chaimaa.katif@edu.uca.ac.ma (C.K.);

Scopus Author ID 57202379369

Received: 25.06.2021; Revised: 15.08.2021; Accepted: 19.08.2021; Published: 21.10.2021

\begin{abstract}
Today, emerging infectious diseases caused by multidrug-resistant bacteria (MDRB) are a major public health problem. These bacteria are gradually becoming more resistant to conventional antimicrobial agents. Thus, there is an urgent requirement to explore new antimicrobial compounds. This study focuses on a screening program of marine actinobacteria for useful bioactive compounds against MDRB, and four endophytic actinobacteria strain isolated from the unexploited marine brown alga Carpodesmia tamariscifolia, harvested from the Atlantic coast of Morocco, were screened for their antimicrobial activities using the agar diffusion assay. Fermentation broths of the two selected promising isolates $\mathrm{KC} 179$ and $\mathrm{KC} 180$ were extracted with different organic solvents and showed antibacterial activity against methicillin-resistant Staphylococcus aureus, Acinetobacter baumannii, and Pseudomonas aeruginosa. From the butanolic extract of KC180's culture broth and in addition to the known metabolite desferrioxamine B, a new desferrioxamine derivative, desferrioxamine B2, was purified using flash chromatography and reversed-phase HPLC, and its structure was elucidated using HRMS and NMR spectroscopy. The 16S rRNA molecular taxonomic characterization of the producing strain KC180 showed Streptomyces albidoflavus as the nearest relative, with a sequence similarity of $99.71 \%$.
\end{abstract}

Keywords: endophytic actinobacteria; desferrioxamine; multidrug-resistant bacteria; antibacterial activity; screening; Carpodesmia tamariscifolia.

(C) 2021 by the authors. This article is an open-access article distributed under the terms and conditions of the Creative Commons Attribution (CC BY) license (https://creativecommons.org/licenses/by/4.0/).

\section{Introduction}

The emergence of multidrug-resistant (MDR) bacterial strains has gradually increased over the years [1]. The pathogenic MDR strains have been described in numerous studies and include species like Salmonella typhi, Escherichia coli, Acinetobacter baumannii, Enterococcus faecalis, Streptococcus pneumoniae, and Staphylococcus aureus, which are more 
resistant to several antibiotics than the formerly known strains. These bacteria cause many different infectious diseases and are a significant threat to public health [2-6].

Many biotech or pharmaceutical companies and academic research groups study marine natural products to discover novel chemical molecules with biomedical applications $[7,8]$. Marine ecosystems contribute to a large proportion of the planet's biotic productivity and represent a reservoir of new bioactive compounds with great pharmaceutical potential [9]. In fact, the stressful environmental conditions of these ecosystems have favored the production of a great variety of novel molecules in marine organisms that are unique in terms of diversity, structural, and functional features with respect to compounds isolated from algae as well as their symbionts $[10,11]$.

Marine macroalgae have attracted attention as an untapped source of new bioactive molecules of biomedical interest [12]. Previous research studies have shown that seaweedassociated microorganisms can produce compounds with antibacterial activity against human pathogens [13]. They provide shelter for different endophytic microorganisms that could produce bioactive molecules similar to those produced by their hosts by expressing transferred genes [14]. Macroalgae-associated microorganisms continue to amaze for their capacity to produce chemically unique and biologically important natural products [15]. Nevertheless, the marine habitat is still poorly explored. In this context, we recently started a natural product drug discovery program to study endophytic microorganisms associated with brown seaweed from the Atlantic coast of Morocco. To the best of our knowledge, no study has been conducted about endophytic actinobacteria of the brown macroalga Carpodesmia tamariscifolia and their biological activities. Thus, the objective of this study was the isolation of marine endophytic actinobacteria associated with the brown macroalga $C$. tamariscifolia, and the purification and structure elucidation of bioactive molecules produced by a selected isolate.

\section{Materials and Methods}

\subsection{General experimental procedures.}

HRESIMS data were obtained using a Q Exactive Plus mass spectrometer (Thermo Fisher Scientific) coupled to an UltiMate 3000 HPLC system (Thermo Fisher Scientific). Flash chromatography was performed on a GX-271 Liquid Handler system with a 322-H2 pump (Gilson). Semi-preparative HPLC was conducted on an UltiMate 3000 HPLC system (Thermo Fisher Scientific). Nuclear magnetic resonance (NMR) experiments were performed in $\mathrm{D}_{2} \mathrm{O}$ on an Agilent DD2 spectrometer equipped with an OneNMR probe at $400 \mathrm{MHz}$. NMR spectra were analyzed with ACD/Structure Elucidator Suite 2018.2.

\subsection{Sampling site.}

The samples of Carpodesmia tamariscifolia (syn. Cystoseira tamariscifolia) were collected in march 2018 at low tide from the Northwestern Atlantic coast of Morocco at the

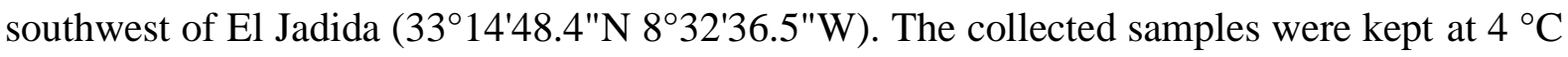
until returned to the laboratory for subsequent treatments.

\subsection{Isolation of endophytic actinobacteria.}

The fresh algal biomass was washed with seawater, brought to the laboratory in sterile polythene bags, and treated 24 hours. The sample surface sterilization protocol for endophyte 
isolation was as follows: The seaweed was washed in sea water and cut into segments of approximately $0.5 \mathrm{~cm}^{2}$. The tissue segments were dipped in $95 \%$ ethanol for 60 seconds, followed by immersion in $1.25 \%$ sodium hypochlorite $(\mathrm{NaOCl})$ solution for 4 minutes and subsequently in $70 \%$ ethanol for 30 seconds. Surface disinfected segments were finally rinsed three times with sterile distilled water and subsequently shaken for 5 minutes in sterile distilled water in order to remove residual traces of $\mathrm{NaOCl}$ [16]. All treated alga pieces were dried on sterile Whatman paper under a laminar flow hood for 30 minutes, deposited on the surface of Petri dishes containing yeast extract-casein hydrolysate agar (YECD) medium [17], supplemented with cycloheximide $(80 \mathrm{mg} / \mathrm{L})$ and nalidixic acid $(20 \mathrm{mg} / \mathrm{L})$ to inhibit the growth of fungi and Gram-negative bacteria [18], respectively, and incubated at $30{ }^{\circ} \mathrm{C}$ for one week [19]. The Petri dishes were observed periodically. The endophytic actinobacteria that grew from the tissue were isolated and purified in Bennet agar without antibiotics [20,21] and finally preserved in glycerol until subsequent use. To test the effectiveness of surface sterilization, 0.1 $\mathrm{mL}$ of the sterile distilled water used during the last rinsing step was placed on nutrient and potato dextrose agar plates to detect epiphytic microbial contaminants [22].

\subsection{Activity of the endophytic actinobacteria isolates against MDR bacteria.}

The endophytic actinobacteria isolated from $C$. tamariscifolia were screened for their ability to produce antibiotic substances against MDRs bacteria. In the first step, the agar pieces of each pure young culture of actinobacteria isolate were inoculated in a $400 \mathrm{~mL}$ Erlenmeyer flask containing $100 \mathrm{~mL}$ of R2YE liquid medium and incubated under agitation (250 rpm) at $30{ }^{\circ} \mathrm{C}$ for one week. One liter of the culture was centrifuged at $12500 \mathrm{~g}$ for 20 minutes, and the recovered supernatant was extracted three times with organic solvents with increasing polarity [23], namely hexanes, dichloromethane, ethyl acetate, and butanol. The obtained organic extracts were concentrated using a rotary evaporator at $40^{\circ} \mathrm{C}$ and stored at $-18{ }^{\circ} \mathrm{C}$ until further use [24]. The antibacterial activity assay was performed using Whatman paper disks $(6 \mathrm{~mm}$ in diameter) impregnated with $20 \mu \mathrm{L}(40 \mathrm{mg} / \mathrm{mL})$ of each obtained organic extract, dried for 40 min under the laminar flow hood, and placed on Petri dishes containing Mueller-Hinton medium previously inoculated with $0.1 \mathrm{~mL}$ of bacterial suspensions $\left(10^{6} \mathrm{CFU} / \mathrm{mL}\right)$ of the tested pathogenic microorganisms [25]. The pathogenic organisms used in this study were five multidrug-resistant bacteria isolated from the intensive care units of the University Hospital Center (UHC) in Marrakesh-Morocco: methicillin-resistant Staphylococcus aureus (MRSA), imipenem-resistant Acinetobacter baumannii (Abri), carbapenem-resistant Pseudomonas aeruginosa (Parc), multi-resistant Klebsiella pneumoniae (Kpr), and multi-resistant Escherichia coli (Ecr) [5]. The Petri dishes were first kept at $4{ }^{\circ} \mathrm{C}$ for 4 hours to allow diffusion of any produced bioactive compound from the paper disc into the agar, and the antibacterial activity was evaluated by measuring the inhibition zone diameters after $24-48 \mathrm{~h}$ of incubation at $37{ }^{\circ} \mathrm{C}[26]$.

\subsection{Fermentation of Streptomyces sp. KC180.}

The actinobacteria isolate $\mathrm{KC} 180$ was cultured in liquid medium R2YE. The culture was grown at $30{ }^{\circ} \mathrm{C}$ for one week, shaking at $(250 \mathrm{rpm})$ in ten baffled Erlenmeyer flasks (500 $\mathrm{mL}$ ) with a culture volume of $100 \mathrm{~mL}$ for each flask. After separating the pellet from the culture broth by centrifugation at $12500 \mathrm{~g}$ for $20 \mathrm{~min}$, one liter of the supernatant ( $\mathrm{pH}$ 7.2) was 
extracted three times with one liter of butanol $(\mathrm{v} / \mathrm{v})$; the obtained organic extracts were combined and dried as described above.

\subsection{Fractionation of the extract and biological screening of the fractions.}

The butanolic extract $(1.4 \mathrm{~g})$ was obtained from the fermentation supernatant of Streptomyces sp. KC180 was dissolved in $10 \mathrm{~mL}$ of methanol (60\% in water) and fractionated by flash chromatography using a C18 flash cartridge (loading volume $5 \mathrm{~mL}, 43 \mathrm{~g} \mathrm{RS} 40 \mathrm{C} 18 \mathrm{ec}$, Chromabond Flash, MACHEREY-NAGEL) and a binary gradient from 5-100\% acetonitrile in water $(0.1 \%$ formic acid each) as the mobile phase at $20 \mathrm{~mL} / \mathrm{min}$ over $30 \mathrm{~min} .34$ fractions were collected in a time-based manner. The fractions were analyzed by HPLC and assayed for antibacterial activity against MRSA, Abri, and Parc, using the agar diffusion assay as described above (Figure S1).

\subsection{Isolation and structure elucidation of 1 and 2.}

The active fraction (fraction $11,50 \mathrm{mg}, \mathrm{t}_{\mathrm{R}}$ from 11.2 to $12.3 \mathrm{~min}$ ) was further purified by semi-preparative HPLC using a $\mathrm{C}_{18}$ column $(250$ x $10 \mathrm{~mm}, 5 \mu \mathrm{m}, 100 \AA$, Luna, Phenomenex) and $12 \%$ acetonitrile in water $(0.1 \%$ formic acid each) as the mobile phase at $4.7 \mathrm{~mL} / \mathrm{min}$ in $16 \mathrm{~min}$ to afford two pure peaks $\left(1,13.5 \mathrm{mg}, \mathrm{t}_{\mathrm{R}} 10.3 \mathrm{~min}\right)$ and $\left(2,3.1 \mathrm{mg}, \mathrm{t}_{\mathrm{R}} 9.3\right.$ min). (Figure S2).

\subsection{Molecular identification of the endophytic actinobacteria. DNA extraction.}

Streptomyces sp. KC180 was grown in $10 \mathrm{~mL}$ of Bennett medium with agitation at 30 ${ }^{\circ} \mathrm{C}$ for $24-48 \mathrm{~h} .1 \mathrm{~mL}$ of well-grown bacterial culture was withdrawn and centrifuged at 14000 rpm for 10 min. DNA extraction was performed according to the kit protocol «Genomic DNA from tissue MACHEREY-NAGEL (NucleoSpin ${ }^{\circledR}$ Tissue)».

\subsection{PCR amplification.}

The obtained genomic DNA was amplified by polymerase chain reaction (PCR) using a 96 universal peqSTAR thermocycler (PEQLAB Biotechnology $\mathrm{GmbH}$ ). The investigated master mix contained $5 x$ buffer $(200 \mu \mathrm{L} / \mathrm{mL})$, dNTPs $(10 \mathrm{mM}$ with $2.5 \mathrm{mM}$ each, $20 \mu \mathrm{L} / \mathrm{mL})$, DMSO $(30 \mu \mathrm{L} / \mathrm{mL})$, MilliQ water $(430 \mu \mathrm{L} / \mathrm{mL})$, and Taq polymerase $(20 \mu \mathrm{L} / \mathrm{mL})$ as well as two primers specific for Actinobacteria $(10 \mu \mathrm{M}, 50 \mu \mathrm{L} / \mathrm{mL}$ each). The used primers were fD1 (5'-AGAGTTTGATCCTGGCTCAG-3') and rP2 (5'- ACGGCTACCTTGTTACGACTT-3') [27]. The PCR program was as follows: an initial denaturation $\left(96^{\circ} \mathrm{C}\right.$ for $\left.2 \mathrm{~min}\right), 30$ cycles of denaturation $\left(96^{\circ} \mathrm{C}\right.$ for $\left.45 \mathrm{~s}\right)$, annealing $\left(56^{\circ} \mathrm{C}\right.$ for $\left.30 \mathrm{~s}\right)$, and extension $\left(72{ }^{\circ} \mathrm{C}\right.$ for $\left.5 \mathrm{~min}\right)$ [27].

2.10. Gel electrophoresis, purification, and sequencing of DNA.

After amplification, PCR products were separated on 1\% agarose gel solubilized in a $65 \mathrm{~mL}$ TAE buffer containing $2.5 \mu \mathrm{L}$ of RotiR-GelStain to ensure that a fragment of the correct size had been amplified [28]. The purification of the amplified 16S rRNA-coding DNA was performed according to the kit protocol «Genomic DNA from tissue MACHEREY-NAGEL (NucleoSpin ${ }^{\circledR}$ Tissue Column)». The primers used for sequencing were the same as mentioned above. The obtained $16 \mathrm{~S}$ rRNA sequences were compared by blast search for similarity with available sequences in EzBioCloud databases (https://www.ezbiocloud.net), a genomic DNA 
database. A phylogenetic tree based on 16S rRNA sequences was constructed with the neighbor-joining algorithm using MEGA version 6 software [29]. The obtained 16S rRNA sequence of Streptomyces sp. KC180 was deposited in the publicly accessible database GenBank under Accession Number MW555177.

\section{Results and Discussion}

In the present study, four endophytic actinobacteria strains were isolated from $C$. tamariscifolia collected at the Moroccan Atlantic coast, and their extracts were subjected to screening for antibacterial compounds against MDR bacteria using an agar diffusion assay. As shown in Table 1, especially the butanolic extract of culture filtrates of isolate KC180 showed antibacterial activity against several tested bacteria.

Table 1. Antibacterial activity of extracts of actinobacteria endophyte isolates against MDR bacteria; diameter of the inhibition zone including disc $(6 \mathrm{~mm})$. MRSA: methicillin-resistant $S$. aureus. Abri: imipenem-resistant

A. baumannii, Parc: carbapenem-resistant P. aeruginosa, Kpr: multi-resistant K. pneumoniae, Ecr: multiresistant E. coli.

\begin{tabular}{|c|c|c|c|c|c|c|}
\hline \multirow{2}{*}{ Strain } & \multirow{2}{*}{ Solvent } & \multicolumn{5}{|c|}{ Inhibition zone [mm] } \\
\hline & & MRSA & Abri & Parc & Kpr & Ecr \\
\hline \multirow{4}{*}{ KC179 } & Hexane & 11 & - & - & - & - \\
\hline & Dichloromethane & - & - & - & - & - \\
\hline & Ethyl acetate & - & - & - & - & - \\
\hline & Butanol & - & 17 & - & - & - \\
\hline \multirow{4}{*}{ KC180 } & Hexane & - & - & - & - & - \\
\hline & Dichloromethane & - & - & - & - & - \\
\hline & Ethyl acetate & - & - & - & - & - \\
\hline & Butanol & 20 & 7 & 8 & - & - \\
\hline
\end{tabular}

The extracts of KC179 were active against imipenem-resistant Acinetobacter baumannii (Abri) (butanolic extract) and methicillin-resistant Staphylococcus aureus (MRSA) (hexane extract), with zones of inhibition of 17 and $11 \mathrm{~mm}$ diameter, respectively. The butanolic extract of KC180 was active against MRSA, carbapenem-resistant Pseudomonas aeruginosa (Parc), and Abri, with 20, 8, and $7 \mathrm{~mm}$ diameter zone of inhibition, respectively. The MDR bacteria multi-resistant Klebsiella pneumoniae (Kpr) and multi-resistant Escherichia coli (Ecr) were resistant to all tested extracts (Table 1). The extracts obtained from KC181 and KC182 did not show any antibacterial activity under the cultivation and extraction conditions used.

The endophytes associated with the brown marine Algae is considered as an important producer of secondary metabolites with great pharmaceutical potentials [30]. In fact, the bacteria associated with the brown marine algae Sargassum spp., Padina gymnosphora, Gracilaria corticate pachynema; Laminaria saccharina, and Valoniopsis showed antibacterial activity against one or more Gram-positive and Gram-negative pathogenic microorganisms [31-34]. In fact, the interest in using marine microorganisms has increased due to the prospect of obtaining abundant biomass subsequently appreciable amounts of secondary metabolites. Their effects on bacteria might differ with the number of molecules effectively interacting with each cell [35]. In addition, many studies reported that bacterial strains isolated from seaweeds are considered an excellent producer of bioactive secondary metabolites [36,37]. The marine environment provides algae-associated microorganisms a unique chemical space to synthesize structurally diverse bioactive secondary metabolites [38]. The work presented here is the first 
study that provides insight into the antibacterial activity of actinobacteria endophytes from the marine alga Carpodesmia tamariscifolia from the coastal Atlantic region of Morocco El Jadida.

Hexane, ether, and chloroform extracts of Carpodesmia tamariscifolia were found to be active against Enterobacter cloacae and Klebsiella pneumonia [39]. Other studies found that the organic extracts of the brown seaweeds Cystoseira barbata and Cystoseira trinodis inhibited the growth of Gram-positive and Gram-negative bacteria [40,41]. Furthermore, the extracts of the endophyte bacteria associated with the brown algae Turbinaria ornate and Turbinaria conoides showed antimicrobial activity against bacterial pathogens E. coli, S. aureus, and Salmonella enterica $[42,43]$. Moreover, many potential therapeutic molecules have been isolated and characterized from actinomycetes. In fact, the Streptomyces species have immense potential as they are known producers of novel biological properties [1]. Furthermore, the endophytic actinomycetes isolate from Cladophora sp. and Ulothrix sp showed antibacterial activity against multidrug-resistant pathogens bacteria such as Enterococcus faecalis, Bacillus subtilis, Klebsiella sp, E.colli, Proteus sp, and Pseudomonas sp [44]. Otherwise, the bacterial extracts isolated from the brown marine algae Hypnea musciformis and Sargassum wightii have the potential to inhibit the growth of E. coli, S. aureus, and B.s subtilis [45]. The unexplored active endophytic actinobacteria from $C$. tamariscifolia promises the discovery of potent and novel bioactive compounds. Because the butanolic extract of isolate KC180 showed the highest activity in our assays for antibacterial activity, it was selected for further studies and purification of the bioactive compounds (Figure S1). The butanolic extract $(1.4 \mathrm{~g})$ obtained from one liter of a culture fermentation in R2YE medium was fractionated by flash chromatography. HPLC analysis of the most active fraction ( $t_{\mathrm{R}}$ from 11.2 to $12.3 \mathrm{~min} ; 50$ $\mathrm{mg}$ ) showed that it contained two compounds, which were isolated by semipreparative HPLC to yield compounds 1 and $\mathbf{2}$ (Figure S2). Their structures were elucidated by HRMS and NMR spectroscopy.

Compound 1 was isolated as a white powder. HRESIMS showed an $[\mathrm{M}+\mathrm{H}]^{+}$ion with $m / z$ 561.3586, corresponding to the molecular formula $\mathrm{C}_{25} \mathrm{H}_{48} \mathrm{~N}_{6} \mathrm{O}_{8}$ (calcd. 561.3588, $\Delta 1.9$ ppm). The ${ }^{1} \mathrm{H}$ spectrum (Figure S3) as well as the sum formula of $\mathbf{1}$ matched the published data for desferrioxamine B [46-48]. Compound 2 was isolated as a white powder. HRESIMS showed an $[\mathrm{M}+\mathrm{H}]^{+}$ion with $\mathrm{m} / \mathrm{z}$ 547.3431, corresponding to the molecular formula $\mathrm{C}_{24} \mathrm{H}_{46} \mathrm{~N}_{6} \mathrm{O}_{8}$ (calcd. 547.3433, $\Delta 1.7$ ppm). The mass difference between 2 and 1 of $14 \mathrm{Da}$ indicated compound $\mathbf{2}$ being a derivative of $\mathbf{1}$ missing one $\mathrm{CH}_{2}$ group. The ${ }^{1} \mathrm{H}$ spectrum of $\mathbf{2}$ was almost identical to the spectrum of $\mathbf{1}$, strengthening this assumption (Figure S3; NMR data summarized in Table 2). The evaluation of the COSY spectrum confirmed that one methylene group was missing at the terminal diamine (butyldiamine instead of pentyldiamine, Figure S4, Table 2). Assignments of all proton and carbon chemical shifts were done based on HMQC and HMBC experiments (Figures S5, S6), allowing us to determine the structure of $\mathbf{2}$ as shown in (Figure 1).

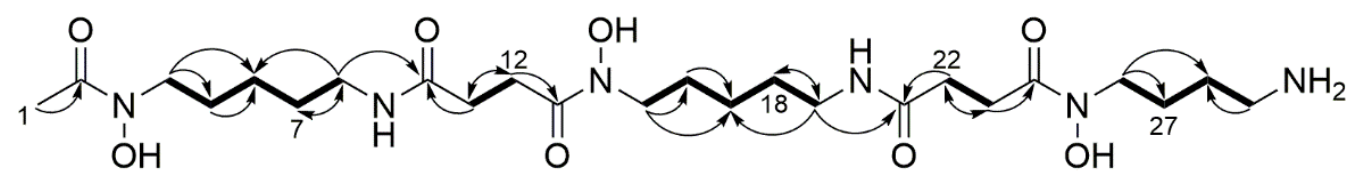

Figure 1. Structure of 2. Bold bonds indicate COSY correlations. Arrows indicate HMBC correlation

Table 2. ${ }^{1} \mathrm{H}(400 \mathrm{MHz})$ and ${ }^{13} \mathrm{C}(100 \mathrm{MHz})$ NMR data for $\mathbf{2}$ in $\mathrm{D}_{2} \mathrm{O} .{ }^{13} \mathrm{C}$ chemical shifts for 2 were extracted from the $2 \mathrm{D}$ spectra 


\begin{tabular}{|c|c|c|c|}
\hline & 1 & \multicolumn{2}{|c|}{2} \\
\hline Position & $\delta_{H}(J$ in $H z)$ & $\delta_{C}$ & $\delta_{H}(J$ in $H z)$ \\
\hline 1 & $2.11, \mathrm{~s}$ & 19.8 & $2.10, \mathrm{~s}$ \\
\hline 2 & - & 174.2 & - \\
\hline 4 & $3.58, \mathrm{t}(6.9)$ & 48.1 & $3.59, \mathrm{t}(7.0)$ \\
\hline 5 & $1.62, \mathrm{~m}$ & 26.0 & $1.60, \mathrm{~m}$ \\
\hline 6 & $1.29, \mathrm{~m}$ & 23.7 & $1.28, \mathrm{~m}$ \\
\hline 7 & $1.48, \mathrm{~m}$ & 28.4 & $1.50, \mathrm{~m}$ \\
\hline 8 & $3.14, \mathrm{t}(6.7)$ & 39.7 & $3.14, \mathrm{t}(6.7)$ \\
\hline 10 & - & 175.4 & - \\
\hline 11 & $2.46, \mathrm{t}(7.0)$ & 30.8 & $2.48, \mathrm{t}(6.9)$ \\
\hline 12 & $2.76, \mathrm{t}(7.0)$ & 28.1 & $2.77, \mathrm{t}(6.8)$ \\
\hline 13 & - & 174.7 & - \\
\hline 15 & $3.58, \mathrm{t}(6.9)$ & 48.1 & $3.59, \mathrm{t}(7.0)$ \\
\hline 16 & $1.62, \mathrm{~m}$ & 26.0 & $1.60, \mathrm{~m}$ \\
\hline 17 & $1.29, \mathrm{~m}$ & 23.7 & $1.28, \mathrm{~m}$ \\
\hline 18 & $1.48, \mathrm{~m}$ & 28.4 & $1.50, \mathrm{~m}$ \\
\hline 19 & $3.14, \mathrm{t}(6.7)$ & 39.7 & $3.14, \mathrm{t}(6.7)$ \\
\hline 21 & - & 175.4 & - \\
\hline 22 & $2.46, \mathrm{t}(7.0)$ & 30.8 & $2.48, \mathrm{t}(6.9)$ \\
\hline 23 & $2.76, \mathrm{t}(7.0)$ & 28.1 & $2.77, \mathrm{t}(6.8)$ \\
\hline 24 & - & 174.7 & - \\
\hline 26 & $3.60, \mathrm{t}(6.7)$ & 47.6 & $3.64 . \mathrm{t}(6.4)$ \\
\hline 27 & $1.62, \mathrm{~m}$ & 23.4 & $1.69, \mathrm{~m}$ \\
\hline 28 & $1.29, \mathrm{~m}$ & 24.2 & $1.66, \mathrm{~m}$ \\
\hline 29 & $1.48, \mathrm{~m}$ & 39.5 & $2.99, \mathrm{t}(7.2)$ \\
\hline 30 & $2.96, \mathrm{t}(7.5)$ & & \\
\hline
\end{tabular}

The MS/MS spectrum confirmed this structure (Figure S7). Therefore, compound 2 was identified as a new desferrioxamine $B$ derivative with a truncated chain length, which we named desferrioxamine $\mathrm{B}_{2}$. In a precursor-directed biosynthesis approach that aimed to elucidate the biosynthesis of $\mathbf{1}$, compound $\mathbf{2}$ was found to be produced by Streptomyces pilus, a soil bacterium, after the addition of 1,4-diaminobutane to the medium, which led to the production of various desferrioxamine B analogues [46]. Moreover, it has been speculated that 2 is produced by Streptomyces davawensis but not isolated [49]. However, the compound has not been isolated before, and speculations about the structure were only based on MS/MS experiments. Natural occurring desferrioxamine's with different carbon chain lengths between the hydroxamate groups have been reported [50].

The two linear desferrioxamine's $\mathrm{G}_{2 \mathrm{C}}$ and $\mathrm{G}_{2 \mathrm{ct}}$ [51,52], as well as the cyclic desferrioxamine $\mathrm{D}_{2}$ [51], also contains the butyldiamine partial structure that we observed in desferrioxamine $\mathrm{B}_{2}$. They also possess antibacterial activities against uropathogenic Escherichia coli in a low-iron medium [53]. Desferrioxamine B is an iron chelator used to treat iron overload diseases, including hemochromatosis, thalassemia, or iron intoxication, for which it is an essential drug substance [54]. Siderophores and siderophore-mimicks also have potential as cancer therapeutics [55-57]. Interestingly, another study reported no antibacterial activity for desferrioxamine D2 against Gram-positive or -negative bacteria, including E. coli [58]. Desferrioxamine $\mathrm{D}_{2}$ was shown to be a poor iron-chelating agent, while desferrioxamine E, which has one more methylene group than 2, exhibited potent iron-chelating activities [53]. In contrast, desferrioxamine $\mathrm{D}_{2}(\mathbf{2})$ showed weak inhibitory activity against the recombinant enzyme sortase B, while desferrioxamine $\mathrm{E}$ was inactive [58].

Regarding the molecular identification of the selected endophytic actinobacteria isolate. Partial sequencing of the 16S rRNA gene of strain KC180 allowed obtaining a nucleotide sequence of 1348 pb having 99.71\% similarity with Streptomyces albidoflavus (Figure S8). The 16S rRNA sequence was submitted to GenBank (accession number MW555177). 
Furthermore, the comparison of the macroscopic profiles shows no difference between KC180 and the strain Streptomyces albidoflavus, which is characterized by spherical spores, white aerial mass, the reverse sides of the colonies are yellow to pale brown on most agar media and the color of substrate mycelium is pale brown $[59,60]$.

\section{Conclusions}

According to the literature, the present study is the first one that describes the actinobacterium Streptomyces albidoflavus associated with the marine brown macroalga Carpodesmia tamariscifolia as an endophyte with antimicrobial activities. During this screening program for bioactive compounds from underexplored Moroccan ecosystems, we found an endophytic actinomycete from Carpodesmia tamariscifolia to produce the known metabolite desferrioxamine $\mathrm{B}$ and its new derivative desferrioxamine $\mathrm{B}_{2}$ with antibacterial activity against MDR bacteria.

\section{Funding}

This research was performed as part of the project MiMo-ALe, financially supported by the German Federal Ministry of Education and Research (BMBF, FKZ 01DH17046), the Cady Ayyad University (UCA), and Chouaib Doukkali University (UCD).

\section{Acknowledgments}

We acknowledge the Department of Pharmaceutical Biology/Pharmacognosy, Institute of Pharmacy, University of Halle-Wittenberg, Halle, Germany, and the project MiMo-ALe for their support. Many thanks to the Cady Ayyad (UCA) and Chouaib Doukkali universities for providing the laboratories and facilities to carry out this research work.

\section{Conflicts of Interest}

The authors declare no conflict of interest

\section{References}

1. Al-Dhabi, N.A.; Esmail, G.A.; Ghilan, A.K.M.; Arasu, M.V. Isolation and screening of Streptomyces sp. AlDhabi-49 from the environment of Saudi Arabia with concomitant production of lipase and protease in submerged fermentation. Saudi J. Biol. Sci. 2020, 27, 474-479, https://doi.org/10.1016/j.sjbs.2019.11.011.

2. WHO : Antimicrobial resistance Antimicrobial resistance. Available online: https://www.who.int/healthtopics/antimicrobial-resistance (accessed on Jun 27, 2021).

3. Da Silva, G.; Domingues, S. Insights on the Horizontal Gene Transfer of Carbapenemase Determinants in the Opportunistic Pathogen Acinetobacter baumannii. Microorganisms 2016, 4, 29, https://doi.org/10.3390/microorganisms4030029.

4. Megan, K.; Paharik, A.E.; Ackermann, L.W.; Shelton, A.U.; Singh, S.B.; Starner, T.D.; Horswill, A.R. Development of an in vitro colonization model to investigate Staphylococcus aureus interactions with airway epithelia. Cell. Microbiol. 2016, 18, 720-732, , https://doi.org/10.1111/cmi.12543.

5. El mekes, A; Zahlanea, K.; Saida, L.A.; Ouafic, A.T.; Mustapha, B. The clinical and epidemiological risk factors of infections due to multidrug resistant bacteria in an adult intensive care unit of University Hospital Center in Marrakesh-Morocco. J. Infect. Public Health 2020, 13, 7, https://doi.org/10.1016/j.jiph.2019.08.012.

6. Abdullah Al-Dhabi, N.; Ali Esmail, G.; Mohammed Ghilan, A.-K.; Valan Arasu, M.; Duraipandiyan, V.; Ponmurugan, K. Characterization and fermentation optimization of novel thermo stable alkaline protease from Streptomyces sp. Al-Dhabi-82 from the Saudi Arabian environment for eco-friendly and industrial 
applications. J. King Saud Univ. - Sci. 2020, 32, 1258-1264, , https://doi.org/10.1016/j.jksus.2019.11.011.

7. Burragoni, S.G.; Jeon, J. Applications of endophytic microbes in agriculture, biotechnology, medicine, and beyond. Microbiol. Res. 2021, 245, 126691, https://doi.org/10.1016/j.micres.2020.126691.

8. Valdes-Pena, M.A.; Massaro, N.P.; Lin, Y.C.; Pierce, J.G. Leveraging Marine Natural Products as a Platform to Tackle Bacterial Resistance and Persistence. Acc. Chem. Res. 2021, 54, 1866-1877, https://doi.org/10.1021/acs.accounts.1c00007.

9. Reen, F.; Gutiérrez-Barranquero, J.; Dobson, A.; Adams, C.; O'Gara, F. Emerging Concepts Promising New Horizons for Marine Biodiscovery and Synthetic Biology. Mar. Drugs 2015, 13, 2924-2954, , https://doi.org/10.3390/md13052924.

10. Stincone, P.; Brandelli, A. Marine bacteria as source of antimicrobial compounds. Crit. Rev. Biotechnol. 2020, 40, 306-319, https://doi.org/10.1080/07388551.2019.1710457.

11. Wang, C.; Tang, S.; Cao, S. Antimicrobial compounds from marine fungi. Phytochem. Rev. 2021, 20, 85117, https://doi.org/10.1007/s11101-020-09705-5.

12. Barbosa, F.; Pinto, E.; Kijjoa, A.; Pinto, M.; Sousa, E. Targeting antimicrobial drug resistance with marine natural products. Int. J. Antimicrob. Agents 2020, 56, 106005, https://doi.org/10.1016/j.ijantimicag.2020.106005.

13. Zheng, L., X.; Han, H.; Chen, W.; And, L.; Yan, X. Marine bacteria associated with marine macroorganisms : potential antimicrobial resources. Ann. Microbiol. 2005, 55, 119-124.

14. Strobel, G.; Daisy, B. Bioprospecting for Microbial Endophytes and Their Natural Products. Microbiol. Mol. Biol. Rev. 2003, 67, 491-502, https://doi.org/10.1128/mmbr.67.4.491-502.2003.

15. Purity Kaaria. Antimicrobial and cytotoxic activities of secondary metabolites from bacteria associated with marine algae of the Kenya coast, Jomo Kenyatta University of Agriculture and Technology, 2018.

16. Hulikere, M.M.; Joshi, C.G.; Ananda, D.; Poyya, J.; Nivya, T. Antiangiogenic, wound healing and antioxidant activity of Cladosporium cladosporioides (Endophytic Fungus) isolated from seaweed (Sargassum wightii). Mycology 2016, 7, 203-211, https://doi.org/10.1080/21501203.2016.1263688.

17. Coombs, J.T.; Franco, C.M.M. Isolation and Identification of Actinobacteria from Surface-Sterilized Wheat Roots. Appl. Environ. Microbiol. 2003, 69, 5603-5608, https://doi.org/10.1128/AEM.69.9.5603-5608.2003.

18. Barakate, M.; Ouhdouch, Y.; Oufdou, K.; Beaulieu, C. Characterization of rhizospheric soil Streptomycetes from Moroccan habitats and their antimicrobial activities. World J. Microbiol. Biotechnol. 2002, 18, 49-54, https://doi.org/10.1023/A:1013966407890.

19. Boughachiche, F.; Reghioua, S.; Oulmi, L.; Zerizer, H.; Kitouni, M.; Boulahrouf, A.; Boudemagh, A. Isolement d'actinomycetales productrices de substances antimicrobiennes a partir de la sebkha de ain mlila. Sci. Technol. 2005, 0, 5-10.

20. Kumar, B, B.; Das, P.; Maharana, J.; Meena, D.K.; Sahu, T.K.; Rao, A.R.; Chatterjee, S.; Mohanty, B.P.; Sharma, A.P. Functional Screening and Molecular Characterization of Halophilic and Halotolerant Bacteria by 16S rRNA Gene Sequence Analysis. Proc. Natl. Acad. Sci. India Sect. B Biol. Sci. 2015, 85, 957-964, https://doi.org/10.1007/s40011-014-0440-6.

21. Belferkh, A..; Megoura, M. Isolement des actinomycètes à partir d'un sol Saharien et d'une Sebkha de la région d'El-Oued et mise en évidence de leur capacité à dégrader quelques pesticides, Université des Frères Mentouri Constantine Faculté des Sciences de la Nature et de la Vie, 2016.

22. Liu, Y.-H.; Guo, J.-W.; Salam, N.; Li, L.; Zhang, Y.-G.; Han, J.; Mohamad, O.A.; Li, W.-J. Culturable endophytic bacteria associated with medicinal plant Ferula songorica: molecular phylogeny, distribution and screening for industrially important traits. 3 Biotech 2016, 6, 209, https://doi.org/10.1007/s13205-016-05227.

23. Schulz, B.; Draeger, S.; dela Cruz, T.E.; Rheinheimer, J.; Siems, K.; Loesgen, S.; Bitzer, J.; Schloerke, O.; Zeeck, A.; Kock, I.; et al. Screening strategies for obtaining novel, biologically active, fungal secondary metabolites from marine habitats. Bot. Mar. 2008, 51, 219-234, https://doi.org/10.1515/BOT.2008.029.

24. Erbert, C.; Lopes, A.A.; Yokoya, N.S.; Furtado, N.A.J.C.; Conti, R.; Pupo, M.T.; Lopes, J.L.C.; Debonsi, H.M. Antibacterial compound from the endophytic fungus Phomopsis longicolla isolated from the tropical red seaweed Bostrychia radicans. Bot. Mar. 2012, 55, 435-440, https://doi.org/10.1515/bot-2011-0023.

25. Hayouni, E.A.; Chraief, I.; Abedrabba, M.; Bouix, M.; Leveau, J.-Y.; Mohammed, H.; Hamdi, M. Tunisian Salvia officinalis L. and Schinus molle L. essential oils: Their chemical compositions and their preservative effects against Salmonella inoculated in minced beef meat. Int. J. Food Microbiol. 2008, 125, 242-251, https://doi.org/10.1016/j.ijfoodmicro.2008.04.005.

26. Subramaniam, Y.; Mazlan, N.; Hassan, H.; Jaafar, J.N.; Anua, S.M.; Young, T.T.; Al-Humairi, S.N.S. 
Antimicrobial Activity of Musa acuminata Peel Extract against Gram-Positive Bacteria. Int. J. Life Sci. Biotechnol. 2020, 3, 191-196, https://doi.org/10.38001/ijlsb.747883.

27. Cook, A.E.; Meyers, P.R. Rapid identification of filamentous actinomycetes to the genus level using genusspecific 16S rRNA gene restriction fragment patterns. Int. J. Syst. Evol. Microbiol. 2003, 53, 1907-1915, https://doi.org/10.1099/ijs.0.02680-0.

28. Mülhardt, C. Der Experimentator Molekularbiologie/Genomics; Springer Berlin Heidelberg: Berlin, Heidelberg, 2013.

29. Tamura, K.; Stecher, G.; Peterson, D.; Filipski, A.; Kumar, S. MEGA6: Molecular Evolutionary Genetics Analysis Version 6.0. Mol. Biol. Evol. 2013, 30, 2725-2729, https://doi.org/10.1093/molbev/mst197.

30. Kamat, S.; Kumari, M.; Taritla, S.; Jayabaskaran, C. Endophytic Fungi of Marine Alga From Konkan Coast, India-A Rich Source of Bioactive Material. Front. Mar. Sci. 2020, 7, 18, https://doi.org/10.3389/fmars.2020.00031.

31. Kanagasabhapathy, M.; Sasaki, H.; Haldar, S.; Yamasaki, S.; Nagata, S. Antibacterial activities of marine epibiotic bacteria isolated from brown algae of Japan. Ann. Microbiol. 2006, 56, 167-173, https://doi.org/10.1007/BF03175000.

32. Wiese, J.; Thiel, V.; Nagel, K.; Staufenberger, T.; Imhoff, J.F. Diversity of antibiotic-active bacteria associated with the brown alga Laminaria saccharina from the baltic sea. Mar. Biotechnol. 2009, 11, 287300, https://doi.org/10.1007/s10126-008-9143-4.

33. Janakidevi, V.; Yokeshbabu, M.; Umarani, R.; Kumaraguru, A.K. Antagonistic activity of seaweed associated bacteria against human pathogens. Int. J. Curr. Microbiol. Appl. Sci. 2013, 2, 140-147.

34. Susilowati, R.; Sabdono, A.; Widowati, I. Isolation and Characterization of Bacteria Associated with Brown Algae Sargassum spp. from Panjang Island and their Antibacterial Activities. Procedia Environ. Sci. 2015, 23, 240-246, https://doi.org/10.1016/j.proenv.2015.01.036.

35. Baquero, F.; Levin, B.R. Proximate and ultimate causes of the bactericidal action of antibiotics. Nat. Rev. Microbiol. 2021, 19, 123-132, https://doi.org/10.1038/s41579-020-00443-1.

36. Jensen, P.R.; Mincer, T.J.; Williams, P.G.; Fenical, W. Marine actinomycete diversity and natural product discovery. Antonie Van Leeuwenhoek 2005, 87, 43-48, https://doi.org/10.1007/s10482-004-6540-1.

37. Macherla, V.R.; Mitchell, S.S.; Manam, R.R.; Reed, K.A.; Chao, T.H.; Nicholson, B.; Deyanat-Yazdi, G.; Mai, B.; Jensen, P.R.; Fenical, W.F.; et al. Structure-activity relationship studies of salinosporamide A (NPI0052), a novel marine derived proteasome inhibitor. J. Med. Chem. 2005, 48, 3684-3687, https://doi.org/10.1021/jm048995+.

38. Sarasan, M.; Puthumana, J.; Job, N.; Han, J.; Lee, J.S.; Philip, R. Marine algicolous endophytic fungi-a promising drug resource of the era. J. Microbiol. Biotechnol. 2017, 27, 1039-1052, https://doi.org/10.4014/jmb.1701.01036.

39. Ainane, T.; Abourriche, A.; Kabbaj, M.; Elkouali, M.; Bennamara, A.; Charrouf, M.; Talbi, M.; Lemrani, M. Biological activities of extracts from seaweed Cystoseira tamariscifolia: Antibacterial activity, antileishmanial activity and cytotoxicity. J. Chem. Pharm. Res. 2014, 6, 607-611.

40. Tajbakhsh, S.; Ilkhani, M.; Rustaiyan, A.; Larijani, K.; Sartavi, K.; Tahmasebi, R.; Asayesh, G. Antibacterial effect of the brown alga Cystoseira trinodis. J. Med. Plant Res. 2011, 5, 4654-4657.

41. Alghazeer, R.; Whida, F.; Abduelrhman, E.; Gammoudi, F. In vitro antibacterial activity of alkaloid extracts from green, red and brown macroalgae from western coast of Libya. African J. Biotechnol. 2013, 12, 70867091.

42. Do Rosario, M.C.; Poddar, P.; Reddy, S.; Osborne, W.J. Biotechnological applications of Turbinaria ornata and its endophytes. Res. J. Pharm. Technol. 2020, 13, 4231, https://doi.org/10.5958/0974360X.2020.00747.7.

43. Dharmayanti, N.-; Anti, A.; Siregar, R.R.; Sipahutar, Y.H.; Permadi, A.; Siregar, A.N.; Salampessy, R.B.; Sujuliyani, S.; Nurbani, S.Z.; Purnamasari, H.B. Antibacterial potential of symbiont bacteria of brown algae (Turbinaria conoides) obtained from Indonesian waters. Biodiversitas J. Biol. Divers. 2021, 22, 373-377, https://doi.org/10.13057/biodiv/d220145.

44. Muften, N.F.; Mezal, E.H.; Al-ashoor, A. shaker Isolation and Purification of Endophytic Actinomycetes Spp from Local Algaein the Central Marshesof Thi-Qar Provence, Southern of Iraq. Ann. Rom. Soc. Cell Biol. 2021, 25, 9795-9817.

45. Jegan S; Manjusha W Antagonistic, Antibacterial and Anticancer Activity of Marine Macroalgae-Associated Bacteria Collected from Kanyakumari coast. Eur. J. Mol. Clin. Med. 2020, 7, 166-175.

46. Telfer, T.J.; Gotsbacher, M.P.; Soe, C.Z.; Codd, R. Mixing Up the Pieces of the Desferrioxamine B Jigsaw 
Defines the Biosynthetic Sequence Catalyzed by DesD. ACS Chem. Biol. 2016, 11, 1452-1462, https://doi.org/10.1021/acschembio.6b00056.

47. Maglangit, F.; Tong, M.H.; Jaspars, M.; Kyeremeh, K.; Deng, H. Legonoxamines A-B, two new hydroxamate siderophores from the soil bacterium, Streptomyces sp. MA37. Tetrahedron Lett. 2019, 60, 75-79, https://doi.org/10.1016/j.tetlet.2018.11.063.

48. Boggs, M.A.; Mason, H.; Arai, Y.; Powell, B.A.; Kersting, A.B.; Zavarin, M. Nuclear Magnetic Resonance Spectroscopy of Aqueous Plutonium(IV) Desferrioxamine B Complexes. Eur. J. Inorg. Chem. 2014, 2014, 3312-3321, https://doi.org/10.1002/ejic.201402105.

49. Hagihara, R.; Katsuyama, Y.; Sugai, Y.; Onaka, H.; Ohnishi, Y. Novel desferrioxamine derivatives synthesized using the secondary metabolism-specific nitrous acid biosynthetic pathway in Streptomyces davawensis. J. Antibiot. (Tokyo). 2018, 71, 911-919, https://doi.org/10.1038/s41429-018-0088-1.

50. Patai, S.; Rappoport, Z. PATAI'S Chemistry of Functional Groups; Rappoport, Z., Ed.; 1st Editio.; Wiley: United States, 2009.

51. Feistner, G.J.; Stahl, D.C.; Gabrik, A.H. Proferrioxamine siderophores of Erwinia amylovora. A capillary liquid chromatographic/electrospray tandem mass spectrometric study. Org. Mass Spectrom. 1993, 28, 163175, https://doi.org/10.1002/oms.1210280307.

52. Zawadzka, A.M.; Vandecasteele, F.P..; Crawford, R.L.; Paszczynski, A.J. Identification of siderophores of Pseudomonas stutzeri. Can. J. Microbiol. 2006, 52, 1164-1176, https://doi.org/10.1139/w06-077.

53. Mike, L.A.; Tripathi, A.; Blankenship, C.M.; Saluk, A.; Schultz, P.J.; Tamayo-Castillo, G.; Sherman, D.H.; Mobley, H.L.T. Discovery of nicoyamycin A, an inhibitor of uropathogenic Escherichia coli growth in low iron environments. Chem. Commun. 2017, 53, 12778-12781, https://doi.org/10.1039/C7CC07732G.

54. WHO Model List of Essential Medicines; Geneva, 2013.

55. Bernhardt, P. V. Coordination chemistry and biology of chelators for the treatment of iron overload disorders. Dalt. Trans. 2007, 30, 3214-3220, https://doi.org/10.1039/b708133b.

56. Yu, Y.; Wong, J.; Lovejoy, D.B.; Kalinowski, D.S.; Richardson, D.R. Chelators at the Cancer Coalface: Desferrioxamine to Triapine and Beyond. Clin. Cancer Res. 2006, 12, 6876-6883, https://doi.org/10.1158/1078-0432.CCR-06-1954.

57. Kontoghiorghes, G.J.; Efstathiou, A.; Ioannou-Loucaides, S.; Kolnagou, A. Chelators Controlling Metal Metabolism and Toxicity Pathways: Applications in Cancer Prevention, Diagnosis and Treatment. Hemoglobin 2008, 32, 217-227, https://doi.org/10.1080/03630260701727119.

58. Lee, H.-S.; Shin, H.J.; Jang, K.H.; Kim, T.S.; Oh, K.-B.; Shin, J. Cyclic Peptides of the Nocardamine Class from a Marine-Derived Bacterium of the Genus Streptomyces. J. Nat. Prod. 2005, 68, 623-625, https://doi.org/10.1021/np040220g.

59. Islam, M.R.; Jeong, Y.T.; Ryu, Y.J.; Song, C.H.; Lee, Y.S. Isolation, Identification and Optimal Culture Conditions of Streptomyces albidoflavus C247 Producing Antifungal Agents against Rhizoctonia solani AG2-2. Mycobiology 2009, 37, 114-120.

60. Suutari, M.; Rönkä, E.; Lignell, U.; Rintala, H.; Nevalainen, A. Characterisation of Streptomyces spp. isolated from water-damaged buildings. FEMS Microbiol. Ecol. 2002, 39, 77-84, https://doi.org/10.1016/S01686496(01)00199-4. 


\section{Supplementary materials}

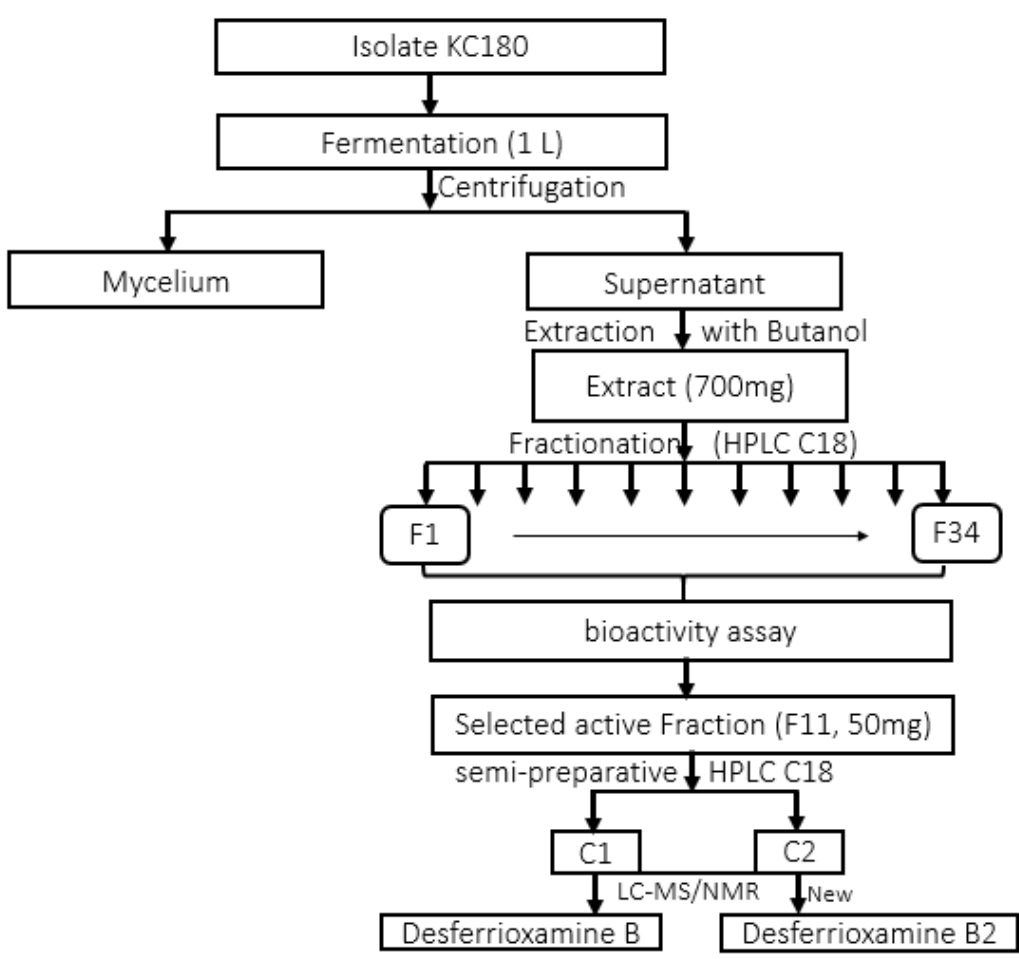

Figure S1. Extraction and purification scheme of desferrioxamine B (1) and B2 (2) from Streptomyces sp. KC180.

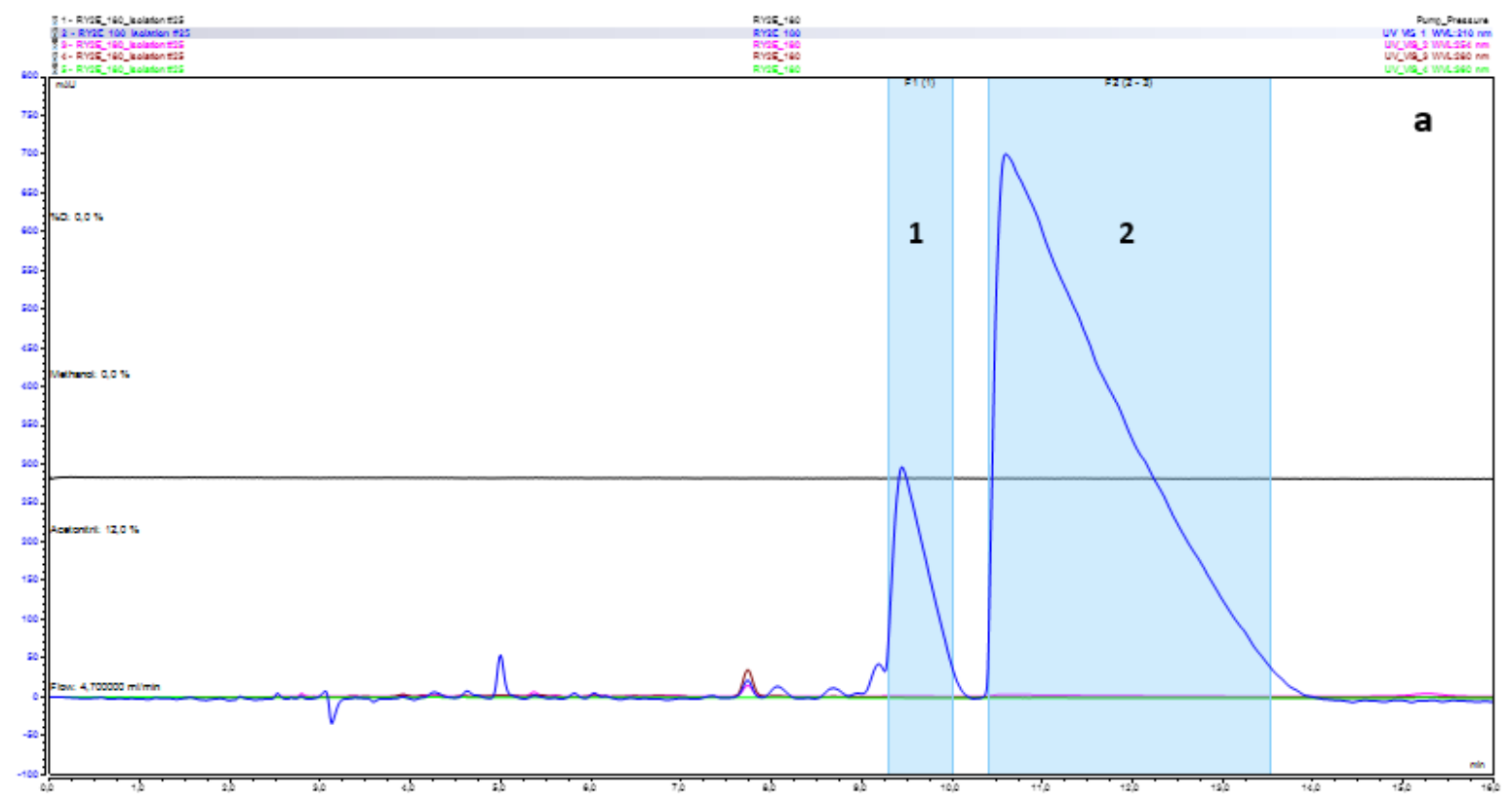

Figure S2. Chromatogram of the semi-preparative HPLC of desferrioxamine B (1) and B2 (2) (HPLC conditions see manuscript). 

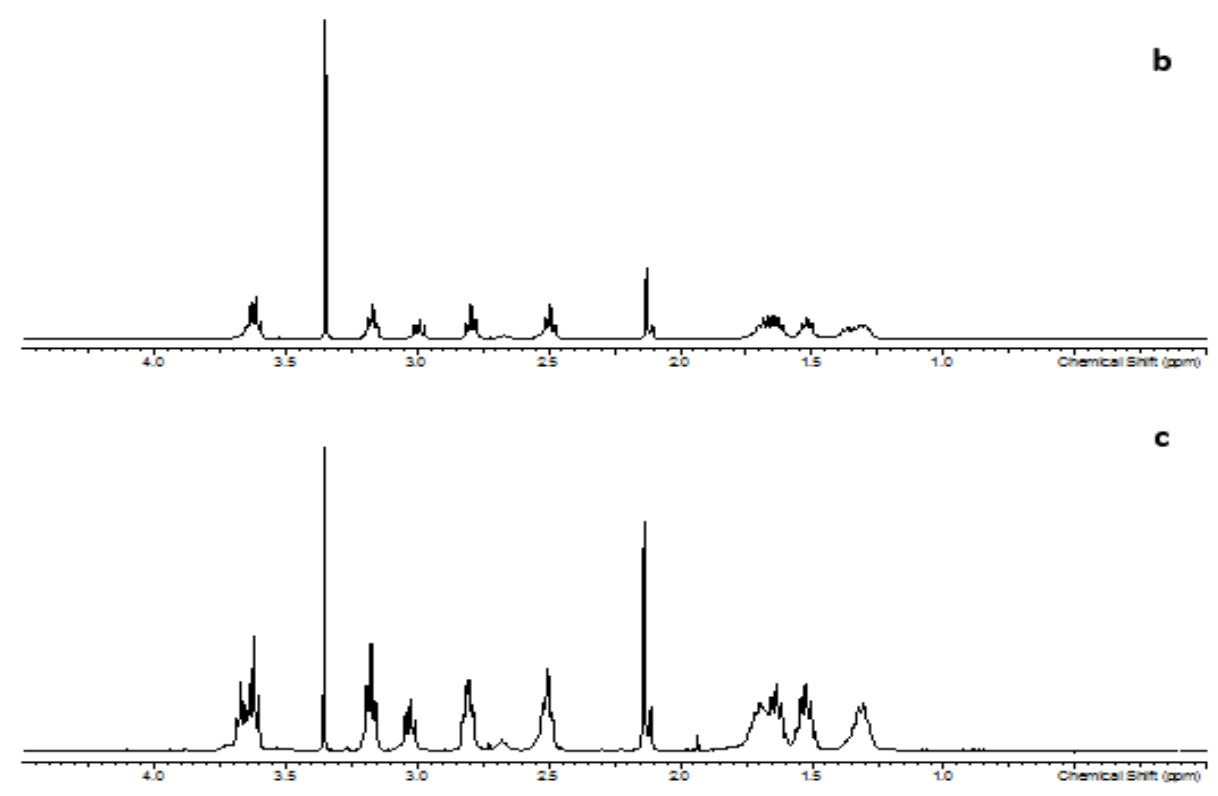

Figure S3. a) 1H NMR spectrum (400 MHz) of 1 in D2O. b) $1 \mathrm{H}$ NMR spectrum (400 MHz) of 2 in D2O.

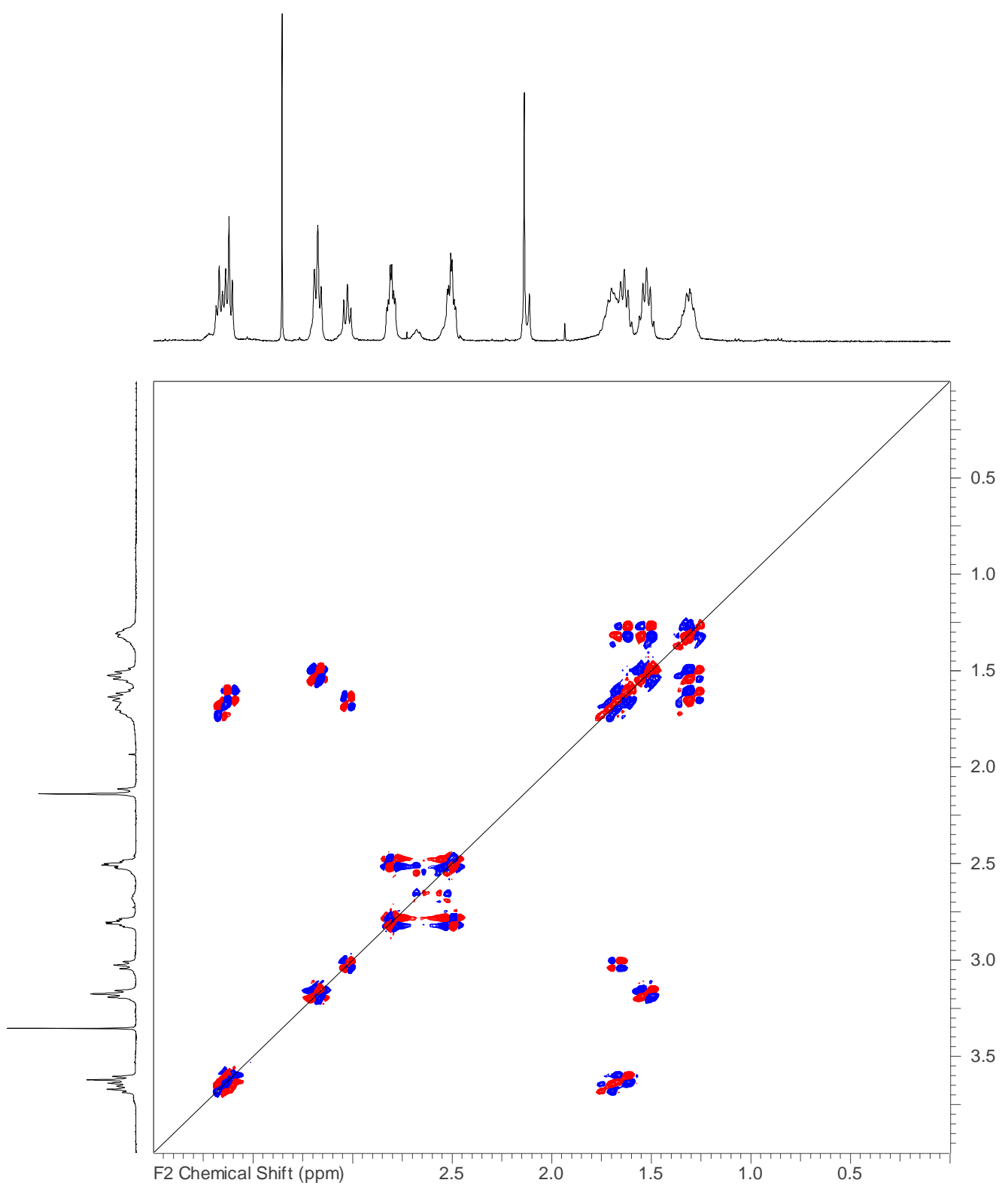

Figure S4. COSY spectrum (400 MHz) of 2 in D2O. 


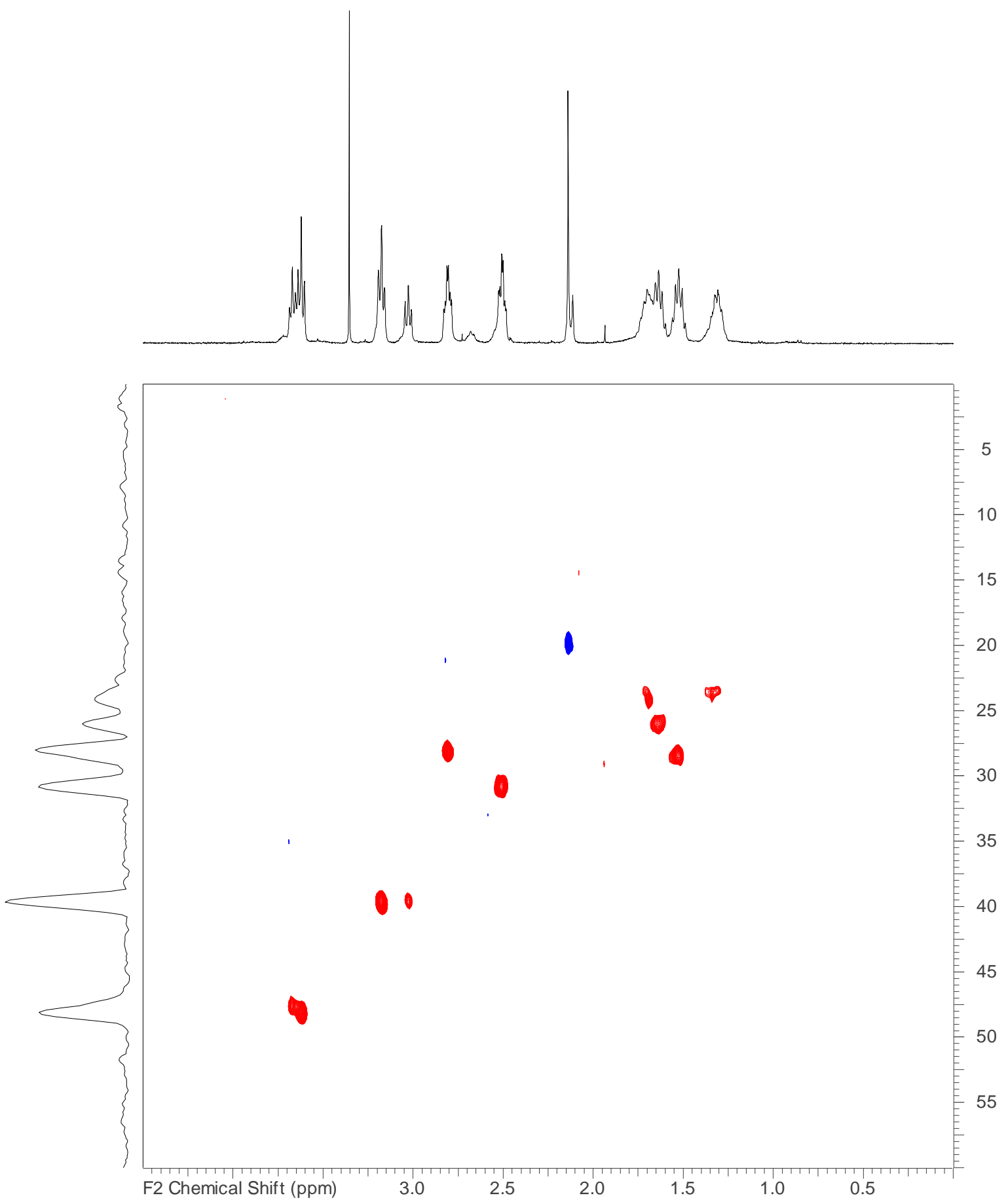

Figure S5. HSQC spectrum (400 MHz) of 2 in D2O. 


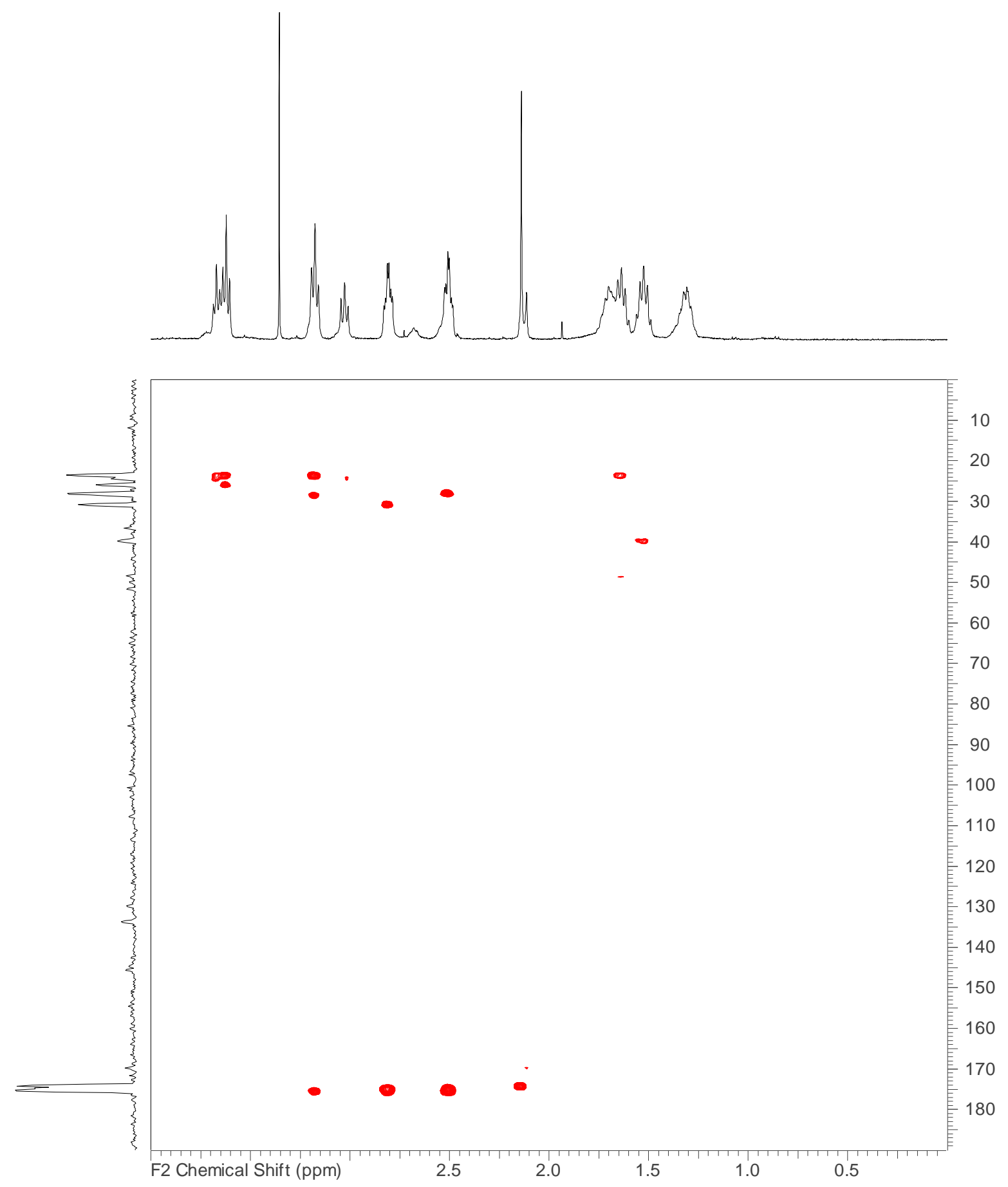

Figure S6. HMBC spectrum (400 MHz) of 2 in D2O. 
180R-1-F11 \#695 RT: 2.16 AV: 1 NL: $1.72 E+005$

T: FTMS - c ESI d Full ms2 545.3289@hcd40.00 [50.0000-575.0000]

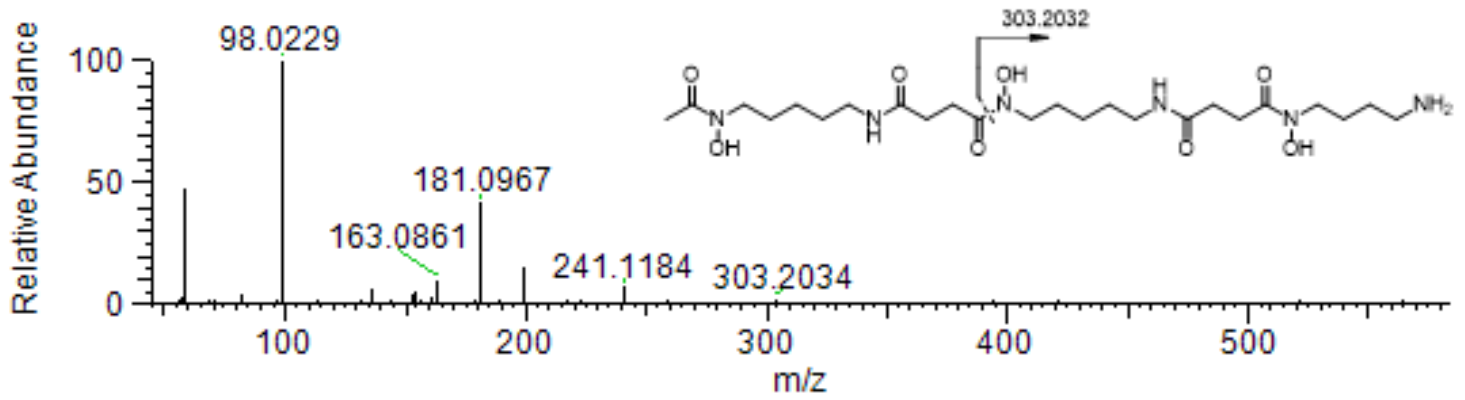

180R-1-F11 \#719 RT: 2.24 AV: 1 NL: $3.63 E+006$

T: FTMS - c ESI d Full ms2 559.3445@hcd40.00 [50.0000-590.0000]

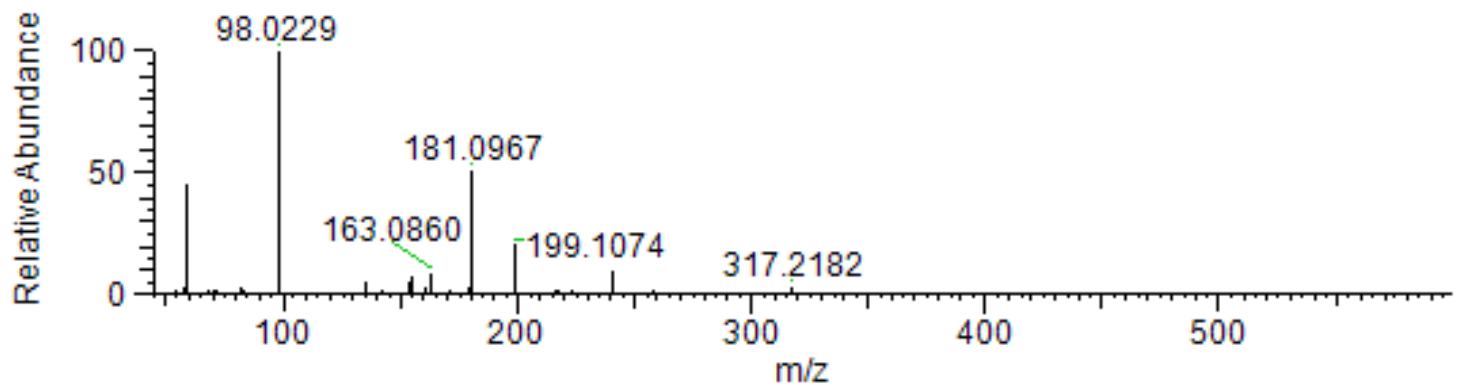

Figure S7. MS/MS-spectra of 1 (top) and 2 (bottom). The only significant difference is the peak at $\mathrm{m} / \mathrm{z}$ 303.2034 / 317.2182 (D CH2).

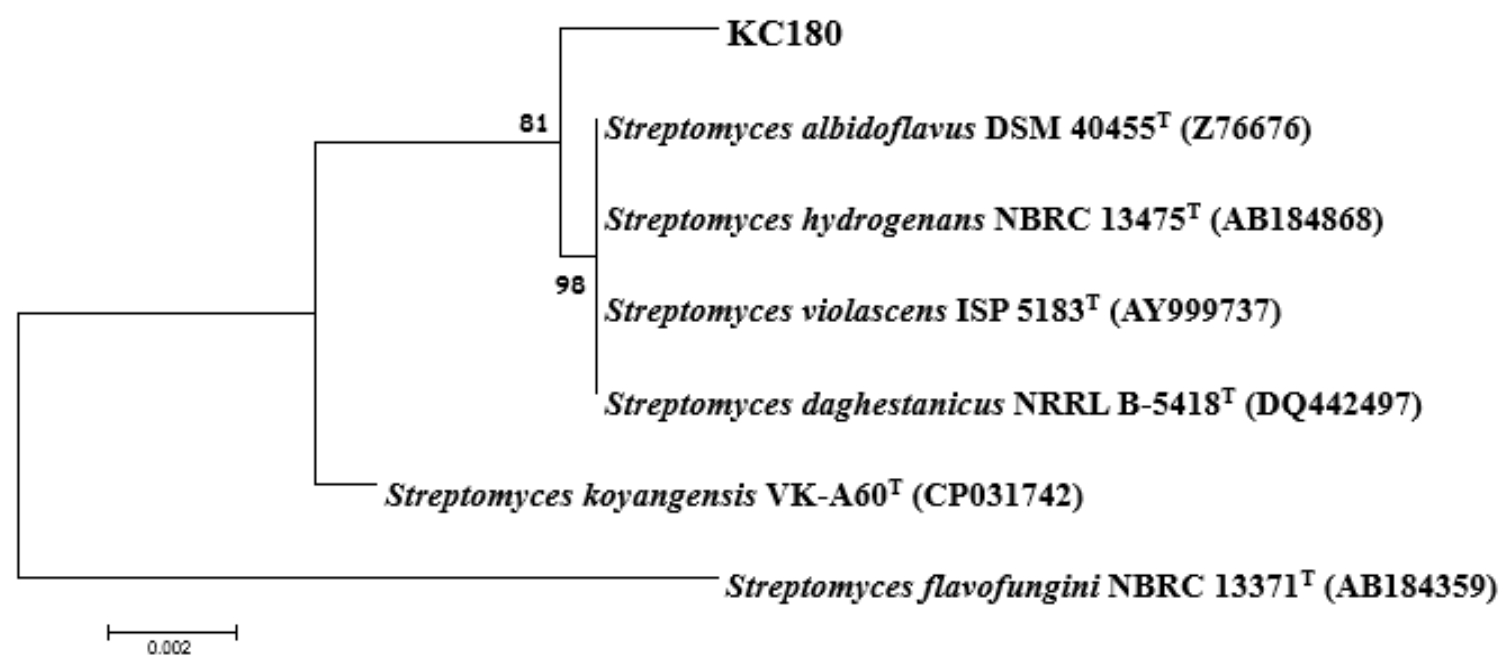

Figure S8. Phylogenetic tree representing the isolate KC180 based on 16S rRNA sequences. 